\title{
Railways in Africa
}

\section{Author(s): Major Darwin}

Source: The Geographical Journal, Vol. 8, No. 5 (Nov., 1896), pp. 488-501

Published by: geographicalj

Stable URL: http://www.jstor.org/stable/1774087

Accessed: 27-06-2016 04:55 UTC

\section{Your use of the JSTOR archive indicates your acceptance of the Terms \& Conditions of Use, available at}

http://about.jstor.org/terms

JSTOR is a not-for-profit service that helps scholars, researchers, and students discover, use, and build upon a wide range of content in a trusted digital archive. We use information technology and tools to increase productivity and facilitate new forms of scholarship. For more information about JSTOR, please contact support@jstor.org.

The Royal Geographical Society (with the Institute of British Geographers), Wiley are collaborating with JSTOR to digitize, preserve and extend access to The Geographical Journal 
as the biological point of view, and contended for a great extension of its habitable period beyond that usually conceded by physicists. A report was read on the biological investigation of oceanic islands; and in Section $\mathrm{H}$ (Anthropology), Prof. Haddon called attention to the need of the immediate study of such islands from the anthropological point of view. In the latter section, the president, Mr. A. Evans, spoke on the pre-historic migrations of people and the origin of European races; and Mr. J. L. Myres read a paper on "Cyprus and the Trade-routes of South-Eastern Europe." Mr. Thiselton Dyer, Director of the Royal Gardens at Kew, gave a lecture in Section K (Botany) on the geographical distribution of plants. Section $G$ (Mechanical Science and Engineering) listened to two communications of much geographical interest, one a "Report on the Effect of Wind and Atmospheric Pressure on Tides;" the other by Mr. G. F. Lyster, on "The Physical and Engineering Features of the River Mersey and the Port of Liverpool." Mr. Lyster's paper was felt to be of such value that it was ordered by the General Committee to be printed in full in the Report.

Prof. W. A. Herdman, in addition to his arduous duties as local secretary, has edited the Association's "Handbook to Liverpool," which, although smaller than some similar books in the past, is admirably compiled, and will serve as a valuable scientific guide to the Liverpool neighbourhood for years to come. It contains the following chapters: History and Antiquity of Liverpool, by W. H. Picton; Geology of the Country around Liverpool, by G. H. Morton, with a geological map specially compiled; The Vertebrate Fauna of the Liverpool District, by Dr. H. O. Forbes; The Marine Fauna of the District, by Prof. Herdman; The Entomology of the Liverpool District, by W. E. Sharp; The Botany of the Liverpool District, by Robert Brown; The Climate of Liverpool, by W. E. Plummer; The River and the Tides, by Prof. Oliver J. Lodge; Docks, and other Engineering Works, by Prof. H. S. Hele-Shaw and H. Percy Boulnois; Trade and Commerce of Liverpool, by Sir William B. Forwood; Chemical Industries, by Dr. C. A. Kohn. An appendix is added giving some similar particulars relating to the Isle of Man, the scene of one of the largest excursions of members after the close of the meeting.

\section{RAILWAYS IN AFRICA.*}

By Major DARWIN, Sec. R.G.S.

In reviewing the record of geographical work during the past year, all other performances pale in comparison with the feat accomplished by Nansen. It is not merely that he has gone considerably nearer the North Pole than any other explorer, it is not only that he has made one of the most courageous expeditions

* Address delivered to the Geographical Section of the British Association at Liverpool, September 17, 1896, by Major Darwin, as President of the Section. Map,p. 540. 
ever recorded, but he has established the truth of his theory of Polar currents, and has brought back a mass of valuable scientific information. When Nansen comes to England, I am certain that we shall give him a reception which will prove how much we admire the heroism of this brave Norwegian.

Besides the news of this most remarkable achievement, the results of a considerable amount of useful exploratory work have been published since the British Association met last at Ipswich. With regard to other Arctic expeditions, we have had the account of Lieutenant Peary's third season in Northern Greenland, from which place he came back in September last, and to which he has again returned, though without the intention of passing another winter there. In October the Windward brought home more ample information as to the progress of the JacksonHarmsworth Expedition than that communicated by telegram to the Association at Ipswich, and on her return from her remarkably rapid voyage this summer she brought back the record of another year. As to geographical work in Asia, Mr. and Mrs. Littledale returned safely from their explorations of the little-known parts of Tibet; the Pamir Boundary Commission, under Colonel Holdich, has collected a great deal of accurate topographical information in the course of its labours; Dr. Sven Hedin continues his important researches in Turkestan; and the Royal Geographical Society was glad to welcome Prince Heury of Orleans when he came to tell us about his journey near the sources of the Irrawaddy. As to Africa, the most important additions to our knowledge of that continent are due to the French surveyors, who have accurately mapped the recently discovered series of lakes in the neighbourhood of Timbuktu, Lake Faguibine, the largest, being found to be 68 miles in length; Dr. Donaldson Smith has filled up some large blanks in the map of Somaliland; and Mr. and Mrs. Theodore Bent have investigated some interesting remains of ancient gold workings inland of the Red Sea. In other parts of the world less bas been done, because there is less to do. Mr. Fitz Gerald has proved for the first time the practicable character of a pass across the Southern Alps, thus supplementing the excellent work of Mr. Harper and other pioneers of the New Zealand Alpine Club; and Sir W. M. Conway has commenced a systematic exploration of the interior of Spitzbergen, a region to which the attention of several other geographers is also directed.

It is impossible in such a brief sketch to enumerate even the leading events of the geographical jear, but what I have said is enough to remind us of the great amount of valuable and useful work which is being done in many quarters of the world. It is true that if we compare this record with the record of years gone by, we find a marked difference. Then, there was always some great geographical problem to be attacked; the sources of the Nile had to be discovered; the course of the Niger had to be traced; and the great white patches on our maps stimulated the imagination of explorers with the thought of all sorts of possibilities. Now, though there is much to be learned, yet, with the exception of the Poles, the work will consist in filling in the details of the picture, the general outlines being all drawn for us already. Personally I cannot help feeling a completely unreasoning regret that we have almost passed out of the heroic period of geography. Whatever the future may have in store for us, it can never give us another Columbus, another Magellan, or another Livingstone. The geographical discoverers of the future will win their fame in a more prosaic fashion, though their work may in reality ke of even greater service to mankind. There are now few places in the world where the outline of the main topographical features is unknown; but, on the other hand, there are vast districts not yet thoroughly examined. And, in examining these more or less known localities, geographers must take a far wider view than heretofore of their methods of study in order to accommodate themselves to modern conditions. 
But even if we confine our attention to the older and more narrow field of geography, it will be seen that there is still an immense amount of work to be done. We have been filling in the map of Africa during recent years with extraordinary rapidity, but yet that map is likely to remain in a very unsatisfactory condition for a long time to come. Englishmen and other Europeans have always shown themselves to be ready to risk their lives in exploring unknown regions, but we have yet to see how readily they will undertake the plodding work of recording topographical details when little renown is to be won by their efforts. It should be one of the objects of geographical societies to educate the public to recognize the importance of this work, and General Chapman deserves great credit for bringing the matter before the International Congress last year in such a prominent manner. He confined himself to four main recommendations. (1) The extension of accurate topographical surveys in regions likely to be settled by Europeans. (2) The encouragement of travellers to sketch areas rather than routes. (3) The study of astronomical observations already taken in the unsurveyed parts of Africa in a systematic manner, and the publication of the results. (4) The accurate determination of the latitude and longitude of many important places in unsurveyed Africa. I am certain that all geographers are in hearty accord with General Chapman in his views, and it is, perhaps, by continually bringing this matter before the public that we shall best help this movement forward.

Not only do we want a more accurate filling in of the picture, but we have yet to learn to read its lessons aright. The past cannot be understood, and still less can the future be predicted, without a wider conception of geographical facts. Look, for example, at the European colonies on the West Coast of Africa. Here we find that there have been Portuguese settlements on the Gold Coast since the year 1471 , the French possibly having been established there at an even earlier date; whilst we English, who pride ourselves on our go-ahead character, have had trading factories on the coast since 1667. I have here a map showing the state of our geographical knowledge in 1815. Why was it that Europeans have never, broadly speaking, pushed into the interior from their base on the coast, which they had occupied for so many centuries? That they had not done so, at least to any purpose, is proved by this map. Why had four centuries of contact with Europeans done so little even for geographical knowledge at that time? The answer to this question may be said to be mainly historical; but the history of our African colonies can never be understood without a study of the distribution of the dense belt of unhealthy forest along the shore; of the distribution of the different types of native inhabitants; and of the courses of the navigable rivers, all strictly geographical considerations.

Geography is the study of distribution, and early in that study we must be struck with the correlation of these different distributions. If we take a map of Africa, and mark on it all the areas within the tropics covered with dense forest or scrub, we shall find we have drawn a map showing accurately the distribution of the worst types of malarial fever; and that we have also indicated with some approach to accuracy - with, however, notable exceptions-the habitat of the lowest types of mankind. These are the facts which give the key to understanding why the progress of European colonization on the West Coast has been so slow.

Along the coast of the Gulf of Guinea we find settlements of Europeans at more or less distant intervals. All along, or nearly all along this same coast, we find a wide belt of fever-stricken forest, fairly thickly inhabited by uncivilized negro and Bantu tribes. Inside this belt of forest the country rises in altitude, and becomes more open, whilst at the same time there is a distinct improvement in the type of native; and the more we proceed inland, the more marked does this improvement 
become. There appears, in fact, to have been a number of waves of advancing civilization, each one pressing the one in front of it towards these inhospitable forest belts. Near the coast the lowest type of negro is, generally speaking, to be found; then, as the more open country is reached, higher types of negroes are encountered-for example, the Mandingoes of the Senegal region are distinctly higher than the Jolas inhabiting the mouths of the Gambia; and the Hausas of the Sokoto empire are vastly superior to the cannibals of the Oil rivers. In both these cases the higher types are probably not pure negroes, but have Fulah, Berber, or Arab blood in their veins; for we see, in the case of the Fulahs, how they become absorbed into the race they are conquering. Near the Senegal river they are comparatively light in colour, but in Adamawa they are hardly to be distinguished by their features from the negroes they despise. Thus the process appears to have been a double one; the higher race driving some of the lower aboriginal tribes before them out of the better lands, and, at the same time, raising other tribes by means of an admixture of better blood. These waves of advancing civilization seem to have advanced from the north and east, for the more we penetrate in these directions, the higher is the type of inhabitant met with, until at last we reach the pure Berbers and the pure Arabs. Thus there are two civilizing influences visible in this part of Africa; one coming from the north and east-a Mohammedan advance-which keeps beating up against this forest belt and occasionally breaking into it; the other, a Christian movernent, which, until the middle of this century, was brought to a dead halt by this same obstacle. The map of Africa, showing the state of geographical knowledge in 1815, makes it clear that, except in a few cases where rivers helped travellers through these malarial regions, nothing was known about the interior. No doubt much has been done since those days, but this barrier still remains the great impediment to progress from the West Coast; and those who desire our influence to spread more effectively into the interior must wish to see some means of overcoming this obstacle. On the East Coast of Africa the conditions are somewhat different, as there is comparatively little dense forest there; but the districts near that coast are also usually unhealthy, and how to cross those malarial regions quickly into the healthy or less unhealthy interior is the most important problem connected with the development of tropical Africa.

Other influences have been at work, no doubt, in checking our progress from the West Coast. In old days, the European possessions in these districts were mere depôts for the export of slaves. As the white residents could not hope to compete with the natives in the actual work of catching these unfortunate creatures, and as the lower the type the more easily were they caught, as a rule, there was no reason whatever for attempting to penetrate into the interior, where the higher types are met with. But, though this export trade in human beings is now no longer an impediment to progress, the slave trade in the interior still helps to bar the way. When the forest belt is passed, we now come, generally speaking, to the line of demarcation between the Mohammedan and the pagan tribes, and here slave-catching is generally rife; when it is so, the constant raids of the Mohammedan chiefs keep these border districts in a state of unrest, which in every way tends to impede progress. Thus a mere advance to the higher inland regions will not by any means solve all our difficulties, but it will greatly lessen them; and it is universally admitted that the more communication with the interior is facilitated, the more easy will it be to suppress this terrible traffic in human beings. By the General Act of the Brussels Anti-Slavery Conference of 1890-91, it was agreed by the assembled delegates that the construction of roads, and, in particular, of railways, connecting the advanced stations with the coast, and permitting easy access 
to the inland waters, and to the upper courses of rivers, was one of the most effective means of counteracting the slave trade in the interior. Here, then, we have the most formal admission which could be given of the necessity of opening up main trunk lines of communication into the interior.

But not only does geographical knowledge help to demonstrate the necessity of improving the means of communication between the coast and the interior, but it helps us to decide where it is wise to malse our first efforts in this direction. In the first place, it is essential to note that if the continent of Africa is compared with other continents, its general poverty is clearly seen. Mr. Keltie, in his excellent work on the Partition of Africa, tells us that "at present (1895) it is estimated that the total exports of the whole of Central Africa by the east and west coast do not amount to more than 20,000,000l. sterling annually." For the purposes of comparison, it may be mentioned that the export trade of India is between sixty and seventy million sterling annually, and that India is only about one-seventh or oneeighth of the area of the whole of Africa. On the other hand, the trade of India has been increasing by leaps and bounds, largely in consequence of the country being opened out by railways, and there is every reason to hope that somewhat similar results would occur in Africa under similar circumstances, though the lower civilization of the people would prevent the harvest being so quickly reaped. But, however it may be as to the future, the present poverty of Africa is enough to demonstrate the necessity of pushing ahead cautiously and steadily, and of doing so in the most economical manner possible.

M. Decle, in an interesting paper, read before the International Geographical Congress in London last year, strongly advocated the construction of cheap roads for use by the natives, taking precautions to prevent any traffic in slaves along them. His suggestions are well worthy of consideration; but the cost of transport along any road would, I should have thought, soon have eaten up any profits on the import or export trade to or from Africa. What must be done in the first instance is to utilize to the utmost all the natural lines of communication which require little or no expenditure to render them serviceable; in fact, to turn our attention at first to the rivers and to the lakes. I have already pointed out that the early maps of Africa prove that the rivers have almost invariably been the first means of communication with the interior, and until this continent is rich enough to support an extensive railway system, we must rely largely on the waterways as means of transport.

It may be as well here to remark that geographical knowledge is often required in order to control the imagination. I do not know why it is, but almost every one will admit that, if he sees a lake of considerable size depicted on a map, he immediately feels a desire to visit or possess that locality in preference to others. A lake may be of far less commercial value than an equal length of thoroughly navigable river, and yet it will always appear more attractive. Look at the way in which the English, the French, and the Germans are all pressing forward to Lake Chad; and yet Lake Chad is in reality not much more than a huge swamp, and, in all probability, it is excessively unhealthy. Again, it is probable that the Albert Nyanza will prove to be of comparatively small value, because the mountains come down so close to its shores. Of course, the great lakes form an immensely important feature in African geography, but we must judge their commercial value rationally, and without the bias of imagination.

To develop the traffic along the rivers and on the lakes is the first stage in the commercial evolution of a continent like Africa. But it cannot carry us very far. Africa is badly supplied with navigable rivers, chiefly as a natural result of the general formation of the land. The continent consists, broadly speaking, 
of a huge plateau, and the rivers flowing off this plateau are obstructed by cataracts in exactly the places where we most want to use them-that is, when approaching the coasts. The second stage in the commercial evolution will therefore be the construction of railways with the view of supplementing this river traffic. Finally, no doubt, a further stage will be reached, when railways will cut out the rivers altogether; for few of the navigable rivers are really well suited to serve as lines of communication. This last stage is, however, so far off that we may neglect it for the present; though it must be noted that there are some parts of Africa where there are no navigable rivers, and where, if anything is to be done, it must be entirely by means of railways.

Thus, as far as the immediate future is concerned, the points to which our attention should be mainly directed are (1) the courses of the navigable parts of the rivers, and (2) the routes most suitable for the construction of railways in order to connect the navigable rivers and lakes with the coast. As to the navigable rivers, little more remains to be discovered with regard to them, and we can indicate the state of our geographical knowledge on this point with sufficient accuracy for our purposes by means of a map. Of course the commercial value of a waterway depends greatly on the kind of boats which can be used, and that point cannot well be indicated cartographically.

As to the railways, we must study the physical features of the country through which the proposed lines of communication would pass. All the obstacles on rival routes should be most carefully surveyed when considering the construction of railways in an economical manner. Great mountain chains are seldom met with in Africa, and from that point of view the continent is as a whole remarkably free from difficulties. But drifting sand is often a serious trouble, and that is met with commonly enough in many parts. Wide tracts of rocky country also form serious impediments, both because of the cost of construction, and also because the supply of water for the engines becomes a problem not to be neglected. Such arid and sandy districts are, of course, thinly inhabited, and we may, therefore, generally conclude that where the population is scanty, there railway engineers will have special difficulties to face. On the other hand, dense forests are also very unsuitable. We have not much experience to guide us, but it would appear probable that the initial expense of clearing the forest, and the cost of maintenance, in perpetually battling against the tropical vegetable growth, will be very heavy; for it will not do to allow the line to be in constant danger of being blocked. The dampness of the forest, which will cause all woodwork and wooden sleepers to rot, will be no small source of trouble, and the virulent malarial fevers, always met with where the vegetation is very rank, will add immensely to the difficulty, both of construction and of maintenance. The health of the European employés will be a most serious question in considering the construction of railways in all parts of tropical Africa, for the turning up of the soil is the most certain of all methods of causing an outbreak of malarial fever; and the evil results would be most severely felt in constructing ordinary railways in dense forests. In making the short Senegal railway, where the climate is healthier than in many of the districts further south, the mortality was very great. Perhaps we shall have to modify our usual methods of construction so as to mitigate this danger, and, in connection with this subject, I may perhaps mention that the Lartigue system seems to be specially worthy of consideration-a system by which the train is carried on a single elevated rail. This is perhaps travelling rather wide of the mark of ordinary geographical studies, but it illustrates the necessity of a thorough examination of the environment before we try to transplant our own methods to other climes.

No. V.-Nov EM BER, 1896.] 
We may, however, safely conclude that we must as far as possible avoid both dense forests and sandy and rocky wastes in the construction of our first railways.

Then, as to the lines of communication, considered as a whole, rail and river combined, we must obviously, if any capital is to be expended, make them in the directions most likely to secure a profitable traffic. In considering this part of the question, it will be seen that there are several different problems to be discussed: (1) trade with the existing population in their present condition; (2) trade with the native inhabitants when their countries have been further developed with the aid of European supervision; and (3) trade with actual colonies of European settlers. To many minds the last of these problems will appear to be the most important, and in the end it may prove to be so. But the time at my disposal compels me to limit myself to the consideration of trade with the existing native races within the tropics, with only an occasional reference to the influence of white residents. We must, no doubt, carefully consider which are the localities most likely to attract those Europeans who go to Africa with the view of establishing commercial intercourse and commercial methods in the interior; and there can be no doubt that considerations of health will play a prominent part in deciding this point. Moreover, as the lowest types of natives have few wants, the more primitive the inhabitants of the district opened up, the less will be the probability of a profitable trade being established. For both these reasons the coast districts are not likely in the end to be as good a field for commercial enterprise as the higher lands in the interior; for the more we recede from the coast, the less unhealthy the country becomes, and the more often do we find traces of native civilization. To put it simply, we must consider both the density of the population and the class of inhabitant in the districts proposed to be opened up. Of course, the exact nature of the products likely to be exported, and the probability of demands for European goods arising amongst the natives of different districts, are vitally important considerations in estimating the profits of any proposed line of railway; but to discuss such problems in commercial geography at length would open up too wide a field on an occasion like this.

If the importance of considering the density of the population in the different districts in such a preliminary survey is admitted, we may then simplify our inquiry by declining to discuss any lines of communication intended to open up regions where the population falls below some fixed minimum-whatever we may like to decide on. Of course, the question of the greater or less probability of a locality attracting white temporary residents is very important, but unless there is a native population ready to work on, there will be little done for many years to come. Politically, it may or may not be right to open up new districts by railways for the sake of finding outlets for our home or our Indian population; but here I am considering the best lines for the development of commerce, taking things as they are. What, then, shall be this minimum of population? 'The population of Bengal is 470 per square mile; of India, as a whole, about 180; and of the United States, about 21 or 22 . If it is remembered that the inhabitants of the United States are, per head, vastly more trade-producing than the natives of Africa, it will be admitted that we may for the present exclude from our survey all districts in which the population does not reach a minimum of 8 per square mile; it might be right to put the minimum much higher than this. On the map now before you, the uncoloured parts show where the density of population does not come up to this minimum, and we can see at a glance how enormously this reduces the area to be considered. The light grey indicates a population of from 8 to 32 per square mile, and the darker grey a denser population than that. Of course, such a map, in the very imperfect state of our knowledge, must be very inaccurate, as I am 
sure the compiler would be the first to admit. On the same map are marked the navigable parts of rivers. I should like to have shown the dense forests also, but the difficulty of giving them with any approach to correctness is at present insuperable.

Here, then, is the kind of map we want in order to consider the broad outline of the questions connected with the advisability of attempting to push lines of communication into the interior. The problem is how to connect the inland parts of Africa, which are coloured grey on this map, with the coast, by practicable lines of communications, at the least cost, with the least amount of dense forest to be traversed, and, in the case of railways, whilst avoiding as far as possible all thinly populated districts.

It is, of course, quite impossible here to discuss all the great routes into the interior, and I should like to devote the remaining time at my disposal to the consideration of this problem as far as a few of the most important districts are concerned, confining myself, as I have said, to trade with existing native races within the tropics. Taking the East Coast first, and beginning at the north, the first region sufficiently populous to attract our attention is the Valley of the Nile, and parts of the Central Sudan. Wadai, Darfur, and Kordofan are but scantily inhabited, according to our map, and this is probably the case now that the Khalifa has so devastated these districts ; but, without doubt, much of this country could support a teeming population, and is capable of great commercial development. The Bahr-el-Ghazal districts are especially attractive, being fertile and better watered than the somewhat arid regions further north. These remarks remind me how difficult it is at this moment to touch on this subject without trenching on politics. Few will deny that the sooner this region is connected with the civilized world the better, and it is only as to the method of opening it up, and as to who is to undertake the work, that burning political questions will arise. The geographical problems connected with the lines of communication to the interior can be considered whilst leaving these two points quite on one side.

A glance at the map reminds us of the well-known fact that below Berber the Nile is interrupted by cataracts for several hundred miles, whilst above that town there is a navigable waterway at high Nile until the Fola rapids are reached, a distance of about 1400 miles, not to mention the 400 to 600 miles of the Blue Nile and the Bahr-el-Ghazal, which are also navigable. The importance of a railway from Suakin to Berber is thus at once evident, and there is perhaps only one other place in Africa where an equal expenditure would open up such a large tract of country to European trade. This route, however, is not free from difficulties. Suakin is hot and unhealthy. Then the railway, about 260 miles in length, passes over uninhabited or thinly inhabited districts the whole way. Though the hills over which it would pass are of no great height, the highest part of the track being under 3000 feet above the sea, it is often said that the desert to be traversed would add greatly to the difficulty of construction. According to Colonel Watson, R.E., however, these difficulties have been greatly exaggerated, for the water-supply would give no great trouble. The six th cataract, between Metemma and Khartum, would, it is said, make navigation for commercial purposes impossible when the waters are low; if this is so, it is probable that this impediment could be overcome by erecting locks, but it is impossible to estimate the cost of such works. Then again, the Nile above Khartum is much obstructed by floating grass or sudd, making navigation at times almost impossible; but it was Gordon's opinion that a line of steamers on the river, even if running at rare intervals, would keep the course of the stream clear; this, however, remains to be proved.

If the canalization of the sixth cataract should prove to be a necessary, but too 
costly an undertaking, then it would be most advisable to carry on the railway beyond that obstacle. This might be done by prolonging the line along the banks of the Nile, or by adopting an entirely different route from Suakin through Kassala. I hope we shall hear something from Sir Charles Wilson as to the relative merits of these proposals during the course of our proceedings. Proposals have also been made for connecting the Nile with other ports on the Red Sea, and all of these suggestions should be carefully examined before a decision is made as to the exact route to be adopted. But in any case, considering the matter merely from a geographical standpoint, and putting politics on one side-a very large omission in the case of the Sudan-it would appear that one or other of these routes should be one of the very first to be constructed in all Africa.

Passing further south, it is obvious from the configuration of the shore, and from the distribution of the population, that the lines of communication next to be considered are those leading to the Victoria Nyanza, and on to the regions lying north and west of the lake.

Two routes for railways from the coast to the Victoria Nyanza have been proposed, one running through the British and the other through the German sphere of influence. Looking at the matter from a strictly geographical point of view, there is perhaps hardly sufficient information to enable us to judge of the relative merits of the two proposals. Both run through an unhealthy coast zone, and both traverse thinly inhabited districts until the lake is reached. The German route, as originally proposed, would be the shorter of the two; but there is some reason to think that the British line will open up more country east of the lake, which will be suitable for prolonged residence by white men. Sir John Kirk, in discussing the question of the possible colonization of tropical Africa by Europeans, said, "These uplands vary from 5000 to 7000 feet in height, the climate is cool, and, as far as known, very healthy for Europeans. The district is separated from the coast by the usual unhealthy zone, which, however, is narrower than elsewhere on the African littoral. Between the coast zone and the highlands stretches a barren belt of country, which attains a maximum width of nearly 200 miles. The rise is gradual, and throughout the whole area to be crossed the climate is drier and the malarial diseases are certainly much less frequent and less severe than in the regions further south." These very advantages, however, may have to be paid for by the greater difficulty of railway construction. Putting aside future prospects, the map shows that the populous region to the west of the lake makes either of these proposed lines well worthy of consideration, though it would perhaps be rash to predict how soon the commerce along them would pay for the interest on the capital expended. What will be the fate of the German project I do not know, but we may prophesy with some confidence that the British line, the construction of which has been commenced, will be completed sooner or later.

The two lines of communication we have discussed-the Suakin and the Victoria Nyanza routes-are intended to supply the wants of widely separated districts ; but, looking to a more distant future, they must sooner or later-probably later-come into competition, one with the other, in attracting trade from the Central Sudan. Before this can occur, communication by steamboat and by railway must be opened up between the coast and the navigable Nile by both routes. This will necessitate a railway being constructed, not only to the Victoria Nyanza, but also from that lake, or round it, to the Albert Nyanza; and, as the Nile is rendered unnavigable by cataracts about Dufile, and as the navigation is difficult between Dufile and Lado, here also a railway might be necessary in order to complete the chain of steam communication with the coast. If goods were brought across the Victoria Nyanza by steamer, and taken down the Nile in the same mann'r from the Albert 
Nyanza to Dufile, this route would necessitate bulk being broken six times before the merchandise was under way on the Nile ; by the Suakin route, on the other hand, bulk would only have to be broken twice, provided the sixth cataract were navigable. Thus, if this latter difficulty does not exist, or can be overcome, and if the sudd on the Nile is not found to impede navigation very much, this Nyanza route will certainly not compete with the Suakin route for any trade on the banks of the navigable Nile until a railway is made from the coast to Lado, a distance of over 800 miles as the crow flies, and certainly over 1000 miles by rail. It must be remembered, also, that the Nyanza route passes over mountains 8700 feet above the sea; that the train will have to mount, in all, nearly 13,000 feet in the course of its journey from the coast; and that a difficult gorge has to be crossed to the eastward of the Victoria Nyanza. From these facts we may conclude that it will be a very long time before the Nyanza route will draw any trade from the Central Sudan; so long, that the idea may be neglected for the present.

The line through the British sphere of influence runs to the northern end of Victoria Nyanza, but from Mr. Vandaleur's recent expedition into these regions we learn that a shorter route, striking the eastern shore of the lake, is under consideration. To lessen the expense of construction would be a great boon, but if we look to the more ambitious schemes for the future, something may be said in favour of the original proposal as being better adapted to form part of a line of railway reaching the navigable Nile.

With regard to the comparison between the German and British routes to the Victoria Nyanza, the latest accounts seem to imply that the Germans have practically decided on a line from the coast to Ujiji, with a branch from Tabora to the Victoria Nyanza. This would be a most valuable line of communication; but it seems a pity that capital should be expended in competitive routes when there are so many other directions in which it is.desirable to open up the continent. If the Germans wish to launch out on great railway projects in Africa, let them make a line from the south end of Lake Tanganyika to the northern end of Lake Nyasa, and thence on to the coast; they would thus open up a vast extent of territory, and Baron von Schele tells us that a particularly easy route can be found from Kilva to the lake. Such a line of communication, especially if eventually connected with the Victoria Nyanza to the north, would be more valuable than any other line in Africa in putting an end to the slave trade, as it would make it possible to crect a great barrier, as it were, running north and south across the roads traversed by the slave-traders.

A line through German territory connecting Lake Nyasa with the sea would, no doubt, come into competition with the route connecting the southern end of that lake with the Zambesi, and thus with the coast. The mouths of the Zambesi, though they are passable, will always present some impediment to commerce. But after entering the river navigation is not obstructed until the Murchison Rapids on the Shiré river are reached. Here there are at present 60 miles of portage to be traversed, and this transit must be facilitated by the construction of a railway, if this route is to be properly developed; Mr. Scott Elliot tells us that 120 miles of railway, from Chiromo to Matope, would be necessary for this purpose. Beyond this latter point there is a good waterway to Lake Nyasa. Thus a comparatively short line of railway would open up this lake to European commerce, and this route is likely to be developed at a much earlier stage of the commercial evolution of Africa than the one through German territory above suggested. It will be seen that these routes connect fairly populous districts with the coast, and it must also be recollected that the high plateau between Lake Nyasa and the Kafue river is one of the very few regions in tropical Africa likely to attract white men as more or less permanent residents. 
Further south we come to the Zambesi river, which should, of course, be utilized as far as possible. But this line of communication to the interior has many faults. The difficulties to be met with at the mouths of the Zambesi have already been alluded to. Then the whole valley is unhealthy, and white travellers would prefer any route which would bring them on to high land more quickly. Moreover, the Kebrabasa rapids cause a serious break in the waterway, and, as the river above that point is only navigable for canoes, it is doubtful if it would ever be worth making a railway for the sole purpose of connecting these two portions of the river.

As the population of the upper Zambesi valley is considerable, and as the country further from its banks is said to be likely to be attractive to white men, there can be no doubt of the advisability of connecting it with the coast. This naturally leads us to consider the Beira route, as a possible competitor with the Zambesi. A 60-centimetre railway is now open from Fontesvilla to Chimoio (190 kilometres), and it is probable that during the course of the next two years the construction of the railway will be completed from the port of Beira itself as far as the territory of the Chartered Company. This will form the first step in the construction of a much better line of communication to the upper Zambesi regions than that afforded by the river itself. It is true that the gauge is very narrow, and that the first part of the line passes through very unhealthy districts; but this line will nevertheless be a most valuable addition to the existing means of penetrating into the interior of the continent. It is needless to say that the object of this railway is to open up communications with Mashonaland, not for the purposes now suggested.

South of the Zambesi the map shows us that there are no regions in tropical Africa where the density of the native population reaches the minimum of eight per square mile. Here, however, we come to the gold-fields, where there is attractive force enough to draw white men in great numbers within the tropics, and where, no doubt, some of the most important problems connected with railway communications will have to be solved in the immediate future. But, for reasons of time and space, I have limited myself to the discussion of districts within the tropics, where trade with the existing native races is the object in view. The Beira railway dces not in reality come within the limits I have imposed on myself, except as to its future development. Had time permitted, I should like to have discussed the route leading directly from the Cape to Mashonaland, its relative merits in comparison with the Beira railway, and as to where the two will come into competition one with the other. But I must pass on at once to consider the main trunk routes from the West Coast leading into the interior of Africa.

Passing over those regions on the West Coast where railways would only be commenced because of the probable settlement, temporary or permanent, of white men-passing over, that is, the whole of the German sphere of influence-we first come to more dense native populations near the coast towns of Benguela and St. Paul de Loanda. The latter locality is the more hopeful of the two, according to our map, and here we find that the Portuguese have already constructed a railway leading inland for 191 miles to close to Ambaca. The intention of connecting this railway with Delagoa Bay was originally announced, and I am not aware to what extent this vast project has now been cut down, so as to bring it within the region of practical proposals. A further length of 35 miles is, at all events, being constructed, and 87 more miles have been surveyed. The Portuguese appear to be very active at present in this district, as there are several other railways already under consideration; one from Benguela to Bihe, of which 16 miles is in operation, another from Mossamedes to Huilla Plateau, and a third from the Congo to the 
Zambesi. It is difficult to foretell what will be the outcome of these schemes, but our population map is not very encouraging.

Next we come to the Congo, and here there is a grand opportunity of opening up the interior of the continent. In going up this great stream from the coast we first traverse about 150 miles of navigable waterway, and afterwards we come to some 200 miles of cataracts, through which steamers cannot pass. Round this impediment a railway is now being pushed, 189 kilometres of rails (117 miles) being already laid. Then we enter Stanley Pool, and from this point we have open before us-if Belgian estimates are to be accepted-7000 miles of navigable waterway. If this fact is correct, and if the population is accurately marked on our map, then there is no place in all Africa where 200 miles of railway may be expected to produce such marked results. The districts traversed are unhealthy, and the natives are, generally speaking, of a low type; but in spite of these drawbacks, which no doubt will delay progress considerably, we may confidently predict a grand future for this great natural route into the interior.

To the north of the Congo, the next great navigable waterway met with is the Niger. Again, granting the correctness of the population map, it can be seen at a glance that there is no area of equal size in all Africa so densely inhabited, and no district where trade with the existing native population appears to offer greater inducement to open up a commercial route into the interior. Luckily, little has to. be done in this respect, for the Niger is navigable for light-draft steamers in the full season as far as Rabba, about 550 miles from the sea; here the navigation soon becomes obstructed by rocks; and at Wuru, about 70 miles further up the river, the rapids are so unnavigable that even the light native canoes have to be emptied before attempting a passage, and there are frequent upsets. From Wuru the rapids extend to Wara, after which a stretch of clear and slow-running river is met with. Above this, again, the Altona rapids extend for a distance of 15 . miles, then 15 miles of navigable waterway, and then 20 miles more of rapids are encountered. Yelo, the capital of Yauri, is situated on these latter cataracts, above which the Middle Niger is navigable for a considerable length. The Binue is also navigable in the floods for many miles, the limits being at present unknown; part of the year, however, it is quite impassable except for canoes. The trade with the Western Sudan, which has been made possible by the opening up of this river, is still only in its infancy, and to get the full benefit of this waterway a line of railway ought to be carried on from Lokoja to Kano, the great commercial centre of Hausaland; Mr. Robinson's recent journeys over this country, which we hope to hear about at a later period of our proceedings, have served to confirm the impression that no great physical difficulties would be encountered. The political condition of the country may, however, make the construction of this railway quite impossible for the present; for here we are on the borderland between Mohammedanism and Paganism, where the slave trade always puts great impediments in the path of progress, but where the same circumstances make it so eminently desirable to introduce a higher condition of civilization. The only drawback to the Niger as a line of communication to the Western Sudan is the terribly unhealthy nature of the coast districts which have to be traversed. Any man, who finds a means of combating the deadly diseases here met with, will be the greatest benefactcr that Africa has ever had; but of such a discovery there are but few signs at present.

It is perhaps too soon to speculate as to the best means of opening a trade route to Wadi, and the more central parts of the Western Sudan; for we may be sure that little will be done in this direction for years to come. Several competing routes are possible. From the British sphere, we may try to extend our 
communications eastward from the navigable parts of the Binue. The French, on the other hand, may push northwards from Ubangi; whilst, in a later stage of commercial evolution, the best route of all may be found through German territory, by pushing a railway from the shore in a direct line towards Bagirmi and Wadai. To compare the relative merits of these trunk lines is perhaps looking too far into the future, and traversing too much unknown country, to make the discussion at all profitable.

Proceeding northwards, or rather westwards, along the coast we find ourselves skirting the belt of dense forest already described as being the great obstacle to advance in this part of Africa. It is to be hoped that this barrier will be pierced in several places before long. Naturally we turn our attention to the different spheres of British influence, and here we are glad to learn that there are several railways being constructed or being considered, with a view to opening up the interior.

At Lagos a careful survey of a railway running in the direction of Rabba has been made, and the first section is to be commenced at once. To connect the Niger with the coast in this way would require 240 miles of railway, but the immediate objectives are the towns of Abeokuta and Ibadan, which are said to contain more than a third of a million inhabitants between them. No doubt the populous coast region makes such a line most desirable; but whether it would be wise to push on at all quickly to the Niger, and thus to come into competition with the steamboat traffic on that river, is a very different question.

Surveys have also been made for a railway to connect either Kormantain or Apan on the Gold Coast with Insuaim, a town situated on a branch of the Prah. It is believed that the local traffic will be sufficiently remunerative to justify the construction of this line. But, looking to the further prolongation of this railway into the interior, it appears possible that those who selected this route were too much influenced by the desire to reach Kumasi, which is a political rather than a commercial centre. According to the views I have been advocating to-day, the main object of a railway in this quarter should be the crossing of the forest belt, and if, as there is some reason to believe, that belt is exceptionally wide and dense in this locality, the choice of Kumasi as a main point on the route will have been an unfortunate selection. A little further south, nearer the banks of the Volta, it is probable that more open land would be met with, and, moreover, that river itself, which is navigable for steam launches from Ada to Akusi, would be of use as a preliminary means of transport. It is to be hoped that the merits of a line from Accra through Odumase will be considered before it is too late.

I am now approaching the end of my brief survey of tropical Africa, for the best method of opening communication between the upper Niger and the coast is the last subject I shall touch on. With this object in view, the French have constructed a railway from Kayes, the head of steam navigation during high water, on the Senegal to Bafulabe, with the intention of ultimately continuing the line to Bamaku on the Niger. Unexpected difficulties have been met with in the construction of this railway, and, as the Senegal river between Kayes and St. Louis is only navigable for about a quarter of the year, it would hardly appear as if the selection of this route had been based on sound geographical information. No doubt the French will find some other practicable way of connecting the upper Niger with the coast, and surveys are already in progress with that object in view. It may be worth mentioning that the Gambia is navigable as far as Yarbutenda, and that it affords on the whole a better waterway than the Senegal; it is possible, therefore, that a railway from Yarbutenda to Bamaku might form a better means of connecting the Niger with the coast than the route the French have selected. 
At Sierra Leone a railway is now being constructed in a south-easterly direction with a view of tapping the country at the back of Liberia. But here, as in the case of the Gambia route, political considerations are of paramount importance; for no doubt the best commercial route, geographically speaking, would; have been a line run in a north-easterly direction to some convenient point on the navigable part of the upper Niger. If such a railway were ever constructed, it would connect the longest stretch of navigable waterway in this region with the best harbour on the coast. But the fact that it would cross the Anglo-French boundary is a complete bar to this project at present.

Proposals for connecting Algeria with the upper Niger by rail have often been discussed in the French press, the idea being to unite the somewhat divided parts of the French sphere of influence by this means. If the views here sketched forth as to the necessity of selecting more or less populous districts for the first opening up of lines of communication into the interior are at all correct, these projects would be simple madness. For many a year to come Algeria and the Niger will be connected by sea far more efficiently than by any overland route, and I feel sure that when the details of these plans are properly worked out we shall not find the French wasting their money on such purely sentimental schemes.

I must now conclude, and must give place to the other geographers who have kindly undertaken to read papers to us on many interesting subjects. All I have attempted to do is briefly to sketch out some of the main geographical problems connected with the opening of Central Africa in the immediate future. Such a review is necessarily imperfect, but its very imperfections illustrate the need of more accurate geographical information as to many of the districts in question. Many blunders may have been made by me in consequence of our inaccurate knowledge, and, from the same cause, many blunders will certainly be made in future by those who have to lay out these routes into the interior. In fact, my desire has been to prove that, notwithstanding the vast strides that geography has made in past years in Africa, there is yet an immense amount of valuable work ready for any one who will undertake it.

Possibly, in considering this subject, I have been tempted to deviate from the strictly geographical aspect of the case. Where geography begins and where it ends is a question which has been the subject of much dispute. Whether geography should be classed as a separate science or not has been much debated. No doubt it is right to classify scientific work as far as possible; but it is a fatal mistake to attach too much importance to any such classification. Geography is now going through a somewhat critical period in its development, in consequence of the solution of nearly all the great geographical problems that used to stir the imagination of nations; and for this reason such discussions are now specially to the fore. My own bumble advice to geographers would be to spend less time in considering what geography is and what it is not; to attack every useful and interesting problem that presents itself for solution; to take every help we can get from every quarter in arriving at our conclusions; and to let the name that our work goes by take care of itself.

\title{
FROM TEHERAN TOWARDS THE CASPIAN.
}

\author{
By Lieut.-Colonel HENRY L. WELLS, R.E.
}

Teheran, the capital of Persia, occupies a depression on the lowest slopes of the Elburz range of mountains which, running east and west, separates the entirely dry province of Irak from Gilan and Mazanderan, provinces situated on the 


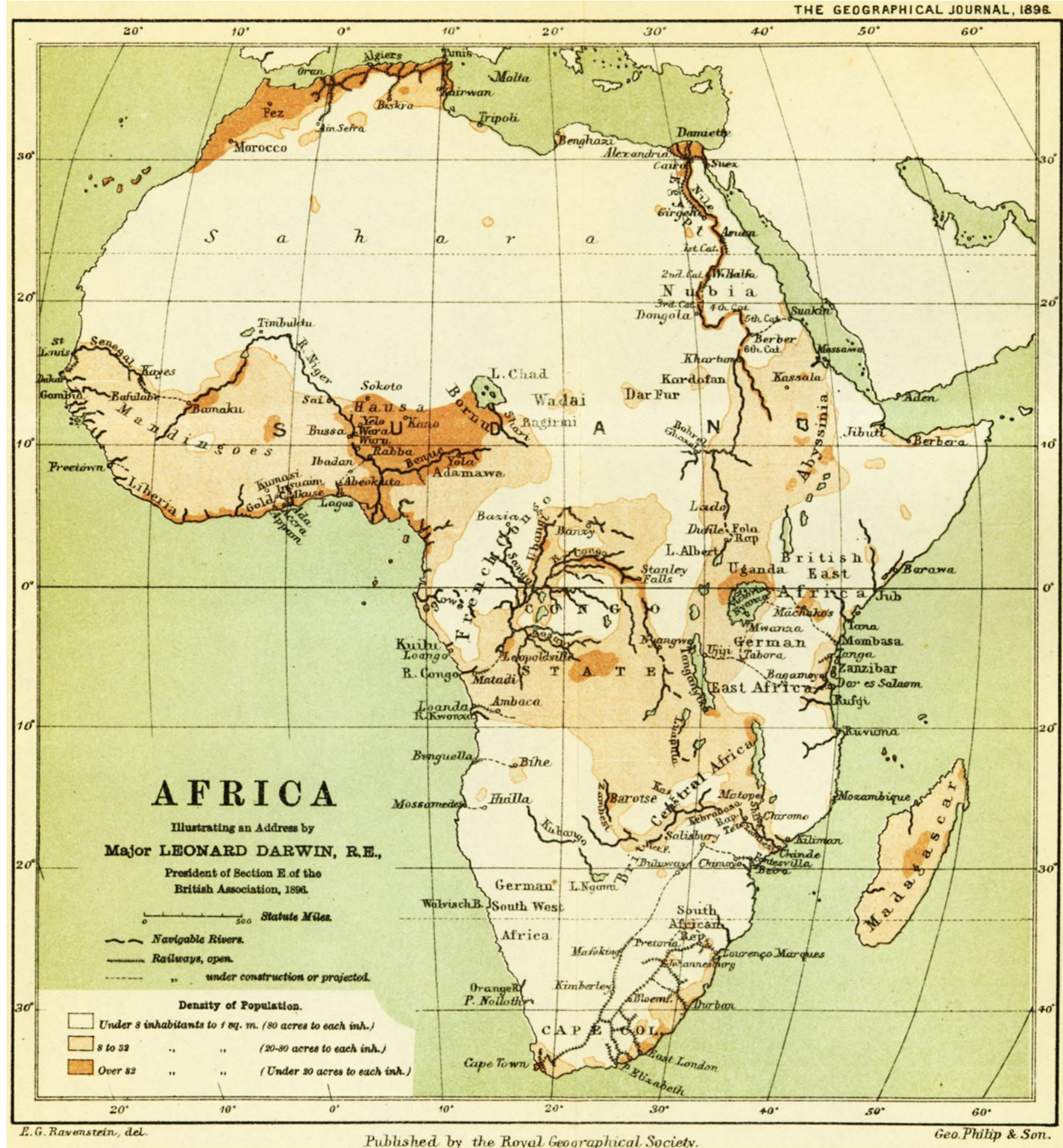

